\title{
EFFECT OF PASTURE RESERVES AND STOCKING RATE ON EWE AND LAMB PERFORMANCE FROM MID-PREGNANCY TO WEANING
}

\author{
D. A. CLARK \\ Grasslands Division, DSIR, Palmerston N orth
}

Abstract

The effect of two stocking rates (16 and 32 ewes/ha) and three initial levels of pasture reserves $(1730,2240$ and $2720 \mathrm{~kg} \mathrm{DM} / \mathrm{ha})$ on animal and pasture production was studied from June to December 1977. Total amount of pasture grown was unaffected by either stocking rate or pasture reserve. At 32 ewes/ha, 96.9\% of net pasture production was eaten and no surplus conserved. At 16 ewes/ ha, $50.4 \%$ was eaten and $1120 \mathrm{~kg} \mathrm{DM} / \mathrm{ha}$ conserved. Increasing initial pasture reserves gave increased ewe liveweight at weaning at 32 ewes/ha, but no response at 16 ewes/ha. There were no treatment effects on single lamb birthweights or weaning weights. The relationship between ewe intake and pasture allowance at different physiological states is discussed.

\section{INTRODUCTION}

A нIян carrying capacity on intensive fat lamb farms may reduce the spring pasture surplus available for conservation and hence aggravate the problem of ewe nutrition in the winter. The potential winter carrying capacity is determined by the following factors: pasture reserves present at the beginning of winter, pasture growth during winter, the proportion that can be removed by grazing, the amount of supplementary feed, and the liveweight loss that can be tolerated by the ewe.

A better knwwledge of the relationships between ewe liveweight change, intake and pasture allowance, and between pasture reserves, residue and regrowth, would allow farmers to budget pasture and supplementary feed more effectively.

The effect of three levels of initial pasture reserves at two stocking rates on ewe performance, intake, and pasture production was examined over a 6-month period.

\section{EXPERIMENTAL}

\section{DESIGN}

The experiment was conducted from 25 June to 9 December 1977 at the Aorangi Experimental Farm in the Manawatu. The 
soil type is Kairanga silt loam (Rijkse and Daly, 1972). Pastures were predominantly perennial ryegrass and white clover.

The experiment was a $3 \times 2$ factorial design replicated twice with three levels of initial pasture availability: 1500 (L), 2250 $(\mathrm{M})$, and $3000(\mathrm{H}) \mathrm{kg} \mathrm{DM} / \mathrm{ha}$ and two stacking rates of 16 and 32 ewes/ha. An area of 4.5 ha was subdivided by electric fences into six 0.5 -ha and six 0.25 -ha plots. Each plot was stocked with eight 5-year-old Romney ewes that had been run with a Romney ram.

\section{MANAGE ME N T}

Pastures were grazed to the required availabilities by ewes on 20 June. Ewes were rotationally grazed with daily shifts throughout the experiment, with a back fence to avoid grazing pasture regrowth older than 4 days. Rotation lengths were the same for all treatments (see Fig. 1) and were based on those recommended by Brougham (1970) .

Lambing began on 22 August and lambs were weighed at birth and then at 3-weekly intervals with the ewes after a 16-hour fast. Ewes and lambs that died were replaced by animals of similar weight, and at the end of lambing the sheep numbers on each replicate were adjusted to nine lambs and eight ewes. Lambs were weaned on 9 December.

On 10 November $60 \%$ of the low-stocked areas was cut by forage harvester and pasture removed to avoid excessively high pasture allowances. No supplementary feed was fed at any time.

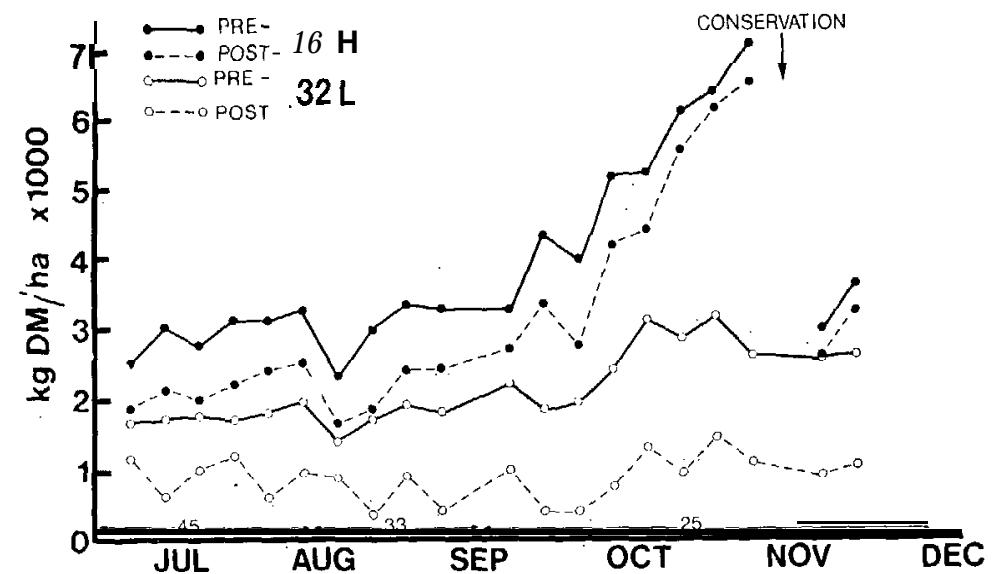

FIg. 1: Seasonal and treatment effect on pre-grazing yield and post-grazing residue. 


\section{Pasture Measurement}

Pasture growth and group intakes were estimated by cutting ten 0.1-m' quadrats to ground level with hand shears before and after grazing on two occasions each week. All herbage was washed to remove soil contamination before drying.

\section{RESULTS AND DISCUSSION}

Pasture Avallability, Residue And Regrowth

Details of pasture production are shown in Table 1. Pasture DM availabilities at the beginning of the experiment were 2718, 2237 and $1729 \mathrm{~kg} / \mathrm{ha}$ for the H, M and L availability groups, respectively. The first rotation was from 26 June to 9 August and pasture residue was lower $(P<0.001)$ on high-stocked pastures than on the low-availability ones $(P<0.05)$.

In the second rotation the pasture availability before grazing was higher $(P<0.001)$ on the low-stocked than high-stocked areas. This difference arose from higher residues in the previous grazing rather than regrowth, which was not significantly different. Similar patterns occurred for the other rotations, with the effect of initial availability on pre-grazing availability persisting until early November.

The seasonal and treatment effects on pre-grazing yield and post-grazing residue are shown in Fig. 1 for the $16 \mathrm{H}$ and $32 \mathrm{~L}$ groups. There was no effect of stocking rate or initial pasture availability on total pasture production. However, the low-stocked pastures gave more conserved feed (1490, 997 and $871 \mathrm{~kg} \mathrm{DM} /$ ha for the $\mathrm{H}, \mathrm{M}$ and $\mathrm{L}$ availability treatments, respectively) and

TABLE 1: PASTURE DM AVAILABILITY, PRODUCTION AND INTAKE $\quad(\mathrm{kg} / \mathrm{ha})$

\begin{tabular}{|c|c|c|c|c|c|c|}
\hline Treatment & $16 H$ & $16 M$ & $16 \mathrm{~L}$ & $32 H$ & $32 \mathrm{M}$ & $32 L$ \\
\hline Initial & 2759 & 2260 & 1796 & 2676 & 2214 & 1663 \\
\hline $\begin{array}{l}\text { Final } \\
\text { availability }\end{array}$ & 5341 & 4969 & 5012 & 2465 & 2619 & 2286 \\
\hline Surplus (S) & 2582 & 2709 & 3216 & -211 & 405 & 623 \\
\hline Intake (I) & 4056 & 3996 & 4004 & 7471 & 7035 & 7288 \\
\hline $\begin{array}{l}\text { Total yield } \\
(S+I) \\
\text { Intake }\end{array}$ & 8128 & 7702 & 8091 & 7260 & 7440 & 7911 \\
\hline ( $\%$ total yield $)$ & 49.9 & 51.9 & 49.5 & 103.9 & 94.6 & 92.1 \\
\hline
\end{tabular}


TABLE 2: PASTURE ALLOWANCES AND INTAKES (kg 1)M/ewe/ day) AT DIFFERENT PHYSIOLOGICAL STATES

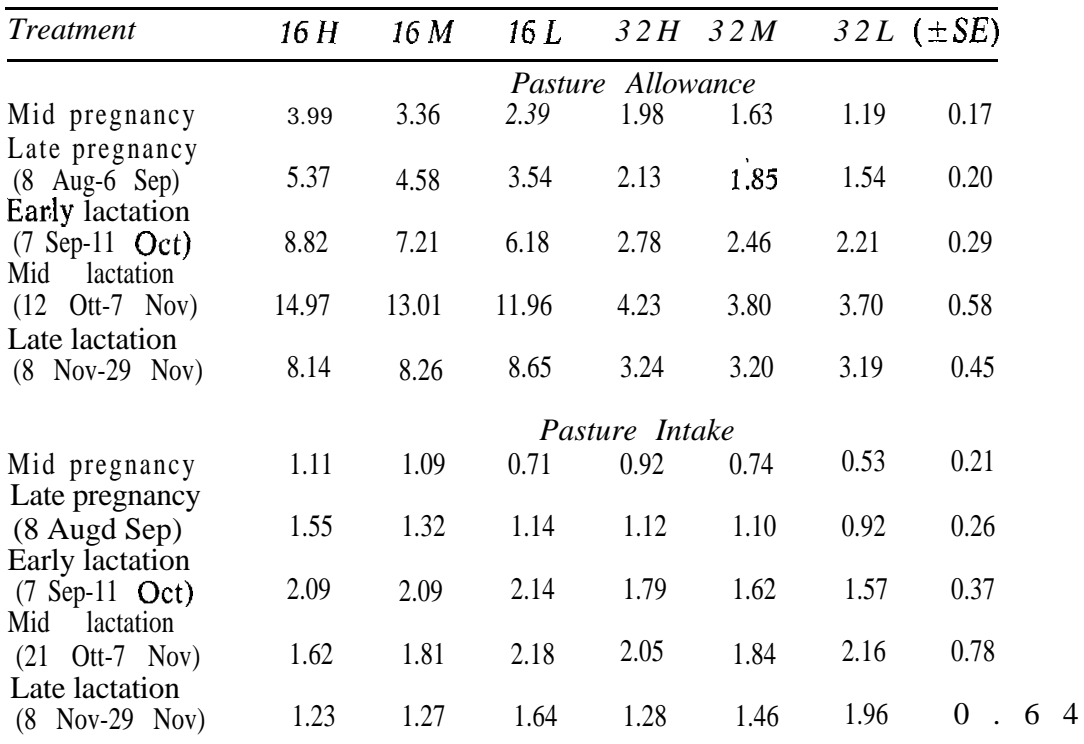

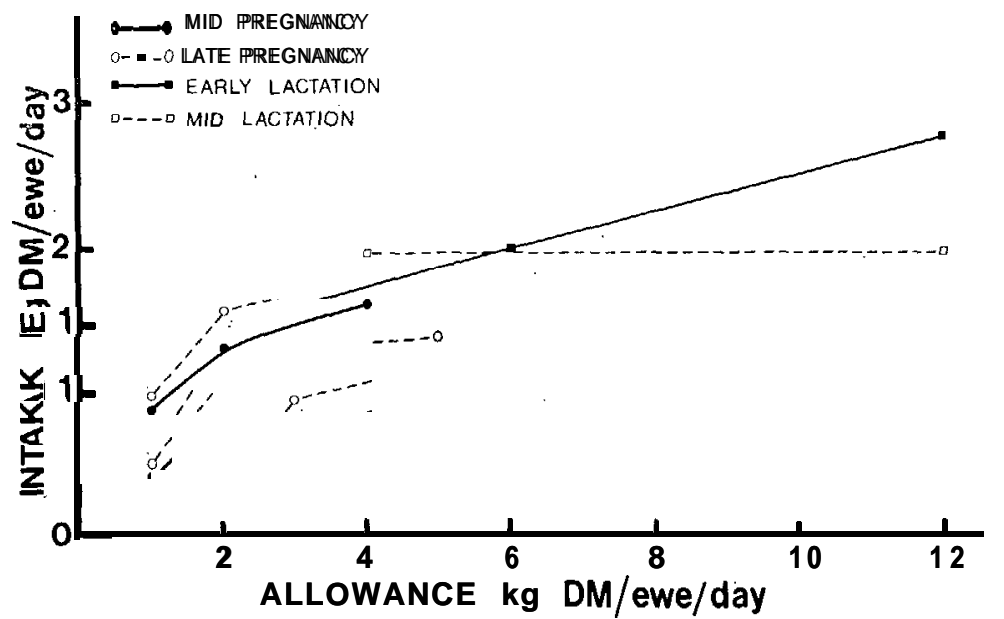

FIG. 2: Relationship between pasture DM intake and allowance. 
had a higher $(\mathrm{P}<0.001)$ level of final pasture availability. The high-stocked pastures provided no conserved feed, but DM intake was $96.9 \%$ of total net pasture production, compared with $50.4 \%$ on the low-stocked areas. High pasture yields in early summer may be a liability unless utilized immediately because of the rapid decline in digestibility and the detrimental effect on intake (Hodgson, 1968).

There is no evidence from this experiment to support the view that leaving pasture residues of greater than $1000 \mathrm{~kg} \mathrm{DM} / \mathrm{ha}$ in winter or spring will result in greater subsequent DM production. Brougham (1959) found no difference in winter and spring production from swards grazed to either 7.5 or $2.5 \mathrm{~cm}$, and Tainton (1974) reported a lower rate of senescence and decomposition and a higher regrowth rate for pastures grazed to $2.5 \mathrm{~cm}$ in the late spring than for those with large amounts of stubble left. Other work reviewed by Smetham (1975) showed that overgrazing of perennial ryegrass did not occur until less than $2 \mathrm{~cm}$ stubble was left. This could explain the depression in yield reported by Harris and Brown (1970) for pastures grazed to 1.25 $\mathrm{cm}$ every fortnight over winter and early spring.

Pasture Allowances and Intakes

The relationship between pasture DM intake and allowance is shown in Fig. 2. The average pasture allowances and intakes for each treatment group at different physiological states of the ewe are shown in Table 2.

In late pregnancy, intake is increased above that in mid pregnancy at an equivalent allowance. An increased allowance from 1 to $3 \mathrm{~kg} \mathrm{DM} /$ ewe/day gave an intake increase from 0.42 to 0.95 $\mathrm{kg} \mathrm{DM}$ /ewe/day in mid pregnancy, but an increase from 0.5 to $1.27 \mathrm{~kg} \mathrm{DM} /$ ewe/day in late pregnancy. Similar increases have been reported by Arnold (1975) and Rattray and Jagusch (1977).

The maintenance requirement of a $50-\mathrm{kg}$ ewe in mid pregnancy was $0.60 \mathrm{~kg} \mathrm{DM} /$ day from an allowance of $1.4 \mathrm{~kg} \mathrm{DM} /$ ewe/day, which is less than the value of $0.9 \mathrm{~kg} \mathrm{DM} /$ day from an allowance of $2.1 \mathrm{~kg} \mathrm{DM} /$ ewe/day reported by Rattray and Jagusch (1977). It is also lower than most other estimates of maintenance for grazing ewes reviewed by Jagusch and Coop (1971). It is possible that the very small break sizes reduced energy expended in walking, and energy required for grazing could have been reduced at low allowances because grazing times were observed to be only 3 to 4 hours. 
In weeks 3 to 6 of lactation, pasture allowance ranged from 2.2 to $9 \mathrm{~kg} \mathrm{DM} /$ ewe/day, with an increase of $0.13 \mathrm{~kg} \mathrm{DM} /$ ewe/ day for $1 \mathrm{~kg} \mathrm{DM} /$ ewe/day increase in allowance. Jagusch and Coop (1971) suggested that intake for lactating ewes should be three times maintenance. Ewes from the $32 \mathrm{~L}$ treatment had an intake of $1.57 \mathrm{~kg} \mathrm{DM} /$ day, or only 2.5 times maintenance, which implies that the pasture allowance of $2.2 \mathrm{~kg} / \mathrm{DM} / \mathrm{day}$ was limiting intake. Pasture residues of less than $500 \mathrm{~kg} \mathrm{DM} / \mathrm{ha}$ further support this conclusion. To achieve intakes of three times maintenance in early lactation it is necessary to offer $6 \mathrm{~kg}$ $\mathrm{DM} /$ ewe/day. The linear response of intake to allowance in early lactation is similar to that reported by Bryant and Cook (1977) for dairy cows.

In weeks 7 to 10 of lactation, pasture allowance varied from 3.7 to $15 \mathrm{~kg} \mathrm{DM} /$ ewe/day, but there was no effect on intake, which averaged $1.94 \mathrm{~kg} \mathrm{DM} /$ ewe/day. Peak feed intake for lactating ewes usually occurs by week 6 of lactation (Vera et al., 1977). It is therefore likely that intakes will fall for ewes in good body condition regardless of allowance, but for thin ewes the negative effect of stage of lactation on intake could be counteracted by an increased appetite to improve body condition. Such behaviour has been reported by Donnelly et al. (1974) and Arnold and Birrell (1977) and is a likely explanation for the failure of increased allowance to give increased, intake in this period, because light ewes were on low allowances and heavy ewes on high allowances.

\section{EWe AND LAMB Liveweights}

Liveweights of the ewes and lambs are shown in Table 3. The low-stocked ewes were heavier $(P<0.05)$ than the high-stocked ones by late pregnancy, and this difference had increased to $5 \mathrm{~kg}$ $(P<0.01)$ at weaning. The level of initial pasture availability had an immediate effect on ewe liveweight, and by weaning the $\mathrm{H}$ and $\mathrm{M}$ availability groups were still heavier $(\mathrm{P}<0.05)$ than the $\mathrm{L}$ group. The results suggest that an additional $1000 \mathrm{~kg}$ $\mathrm{DM} /$ ha of pasture in early winter would enable an extra 3.4 $\mathrm{kg}$ of ewe liveweight to be maintained at weaning at 32 ewes/ha but there would be no effect at 16 ewes/ha. The $32 \mathrm{~L}$ group was the only one to lose weight up to mid lactation, and from then until weaning all groups maintained or increased liveweight.

There was no significant effect on the birthweight of single lambs, although there was a difference of $0.87 \mathrm{~kg}$ between the 
TABLE 3: LIVEWEIGHTS (kg) OF EWES AND LAMBS AT SIXWEEKLY INTERVALS

\begin{tabular}{|c|c|c|c|c|c|}
\hline Date & $\operatorname{Jun} 25$ & Aug 5 & Sep16 & Oct 28 & $\operatorname{Dec} 9$ \\
\hline \multicolumn{6}{|l|}{ Ewes: } \\
\hline $16 \mathrm{H}$ & 49.2 & 56.7 & 60.7 & 59.6 & 58.9 \\
\hline $16 \mathrm{M}$ & 48.3 & 56.4 & 56.0 & 56.7 & 56.7 \\
\hline $16 \mathrm{~L}$ & 48.6 & 52.9 & 52.4 & 57.2 & 58.2 \\
\hline $32 \mathrm{H}$ & 49.4 & 55.1 & 53.4 & 52.0 & 53.7 \\
\hline $32 \mathrm{M}$ & 49.4 & 52.4 & 49.6 & 51.6 & 54.7 \\
\hline $32 \mathrm{~L}$ & 48. 1 & 49.0 & 46.3 & 47.3 & 50.3 \\
\hline$( \pm S E)$ & 0.9 & 1.2 & 1.4 & 1.2 & 1.2 \\
\hline Lambs: & \multicolumn{5}{|c|}{ Birth wt. } \\
\hline $16 \mathrm{H}$ & & 4.93 & 7.65 & 11.53 & 19.18 \\
\hline $16 \mathrm{M}$ & & 4. 62 & 6.89 & 14.32 & 21.13 \\
\hline $16 \mathrm{~L}$ & & 4.53 & 8.41 & 14.94 & 21.81 \\
\hline $32 \mathrm{H}$ & & 4.74 & 7.65 & 14.00 & 21.94 \\
\hline $32 \mathrm{M}$ & & 4.77 & 7.31 & 15.16 & 22.87 \\
\hline $32 \mathrm{~L}$ & & 4.06 & 7.45 & 13.60 & 20.53 \\
\hline$( \pm \mathrm{SE})$ & & 0.35 & 0.64 & 0.81 & 1.00 \\
\hline
\end{tabular}

$16 \mathrm{H}$ and $32 \mathrm{~L}$ groups. However, twin lambs from the former treatment were heavier $(\mathrm{P}<0.01)$ than those from the latter. This is consistent with the results of Russell et al. (1977), who found an effect of moderate undernourishment in late pregnancy on twins but none on singles. Rattray and Jagusch (1977) found no difference for either single or twin birthweights when ewes were offered either 2.0 or $3.6 \mathrm{~kg} \mathrm{DM} / \mathrm{ewe} /$ day in late pregnancy, but the range of allowances from 1.6 to $5.6 \mathrm{~kg} \mathrm{DM} / \mathrm{ewe} /$ day was greater in the present experiment.

There was no treatment effect on the weaning weight of lambs, and no differences at any earlier stage. This suggests that milk production from ewes on low pasture allowances was similar to that on high allowances during early lactation. Lambs were able to graze ahead of the ewes and were therefore unlikety to have had pasture intake restricted by low allowances. Ewes at the higher stocking rate lost $2 \mathrm{~kg}$ liveweight from 5 August to 28 October, while the lower-stocked ewes gained $2.5 \mathrm{~kg}$. This demonstrates the ewe's ability to buffer the lamb from low pasture allowances in early lactation.

\section{CONCLUSIONS}

Neither pasture reserves nor stocking rate had any significant effect on pasture regrowth. At 32 ewes/ha, almost all the net 
pasture growth was consumed. An initial pasture reserve of 1729 $\mathrm{kg} \mathrm{DM} /$ ha was capable of wintering 32 ewes/ha.

Increased pasture reserves gave higher ewe liveweights at 32 but not at 16 ewes/ha, but there was no effect on single lamb birthweight or weaning weight at either stocking rate.

At any given pasture allowance the ewe will increase intake to cope with the extra demands of pregnancy and lactation and will show a greater response to increased allowances during these periods. The ewe's capacity to buffer the lamb from low pasture allowances in early lactation was not exceeded in this experiment.

\section{ACKNOWLEDGEMENTS}

Appreciation is expressed to Dr R. W. Brougham for provision of land and animals at Aorangi, to J. Lancashire for helpful discussions, and to R. Maxwell and G. Owens for technical assistance.

\section{REFERENCES}

Arnold, G. W., 1975. A ust. J. agric. Res., 26: 1017-24.

Arnold, G. W., Birrell, H. A., 1977. Anim. Prod., 4: 343-53.

Brougham, R. W., 1959. N.Z. Jl agric. Res., 2: 1232-48.

1970. Proc. N.Z. Grassld Ass., 32: 137-44.

Bryant, A. M.; Cook, M. A. S., 1977. Proc. Ruakura Fmrs' Conf,, 29: 52. Donnelly, J. R.; Davidson, J. L.; Freer, M., 1974. Aust. J. agric. Res., 25: 813-23.

Harris, A. J.; Brown, K. R., 1970. Proc. N.Z. Grassld Ass., 32: 191-7.

Hodgson, J., 1968. J. agric. Sci., Camb., 70: 47-51.

Jagusch, K.' T.; Coop, I. E., 1971. Proc. N.Z. Soc. Anim. Prod., 31: 224-

$$
34 .
$$

Rattray, P. V.; Jagusch, K. T., 1977. Proc. Ruakura Fmrs' Conf., 29: 49-51. Rijkse, W. C.; Daly, B. C., 1972. N.Z. $/ l$ agric. Res., 15: 117-36.

Russell, A. J. F.; Maxwell, T. J.; Sibbald, A. R.; McDonald, D., 1977. J. agric Sci., Camb., 89: 667-73.

Smetham, M. L., 1975. Proc. N.Z. Grassld. Ass., 37: 91-103.

Tainton, N. M., 1974. J. Br. Grassld Soc., 29: 191-202.

Vera, R. R.; Morris, J. G.; Koong, L. J. 1977. Anim. Prod., 25: 133-53. 